\title{
Religious ecology in sustainable development in the world and Vietnam
}

\author{
Thanh Hang Pham ${ }^{1, *}$, Lan Hien Do $^{1}$, and Ekaterina Nikolaeva ${ }^{2}$ \\ ${ }^{1}$ Institute of Religion and Belief, Ho Chi Minh National Academy of Politics, 135, Nguyen Phong Sac \\ Str., 10000, Hanoi, Vietnam \\ ${ }^{2}$ Chelyabinsk State University, 129, Br. Kashirinykh str., 454001, Chelyabinsk, Russia
}

\begin{abstract}
Religious ecology is a new approach to the research of religions from the angle of ecological issues. The purpose of this approach is to find in the scriptures, theological theories and hermeneutic texts of different religions the values relating to ecology from the perspective of religious cognition, worldview, outlook on life, ethical principles, norms, rituals. Thus, religious ecology considers the ways religious organizations guide their followers' behavior in relation to the environment around, evaluates their roles in dealing with the present environmental problems, thence proposes ways to put the ecological dimension of religions into practice. The paper focuses on the theoretical and practical issues of religious ecology in the word and Vietnam, towards the sustainable development goals.
\end{abstract}

\section{Introduction}

Religious theories have taken into account ecological and environmental issues for a long time, but knowledge they had and the solutions they suggested seems to be disregarded, especially when the secular society holds the upper hand and the religious values depreciated. It is not believed that religions can resolve environmental problems, since religions have been existing together with man for centuries and ecological problems, far from being resolved, are getting more and more serious. However, about three decades ago, the world and Vietnam as well paid more attention to the ecological issues suggested by the religions and their roles in protecting the environment and adapting natural disasters, and started to put them to practice. Those issues will be mentioned in the following parts of the paper.

\section{Materials and methods}

The paper makes use the method of text analysis to collect and systemize documents published domestically and internationally. Based on the data analyses and the investigation into the current practice, the paper aims to consider and evaluate the theoretical ideas and practical activities of the religious ecology in the world and Vietnam.

\footnotetext{
*Corresponding author: thanhhanghh2015@gmail.com
} 


\section{Results}

\subsection{Religious ecology is the topic discussed broadly in current research on religion in the world}

In 1996, for the first time, Center for the Study of World Religions of the Harvard University (USA) set up the "Harvard Project on Religion and Ecology" to establish a large forum for the multireligious conversation among 10 major religions in the world, including Buddhism, Christianity, Protestantism, Islam, Judaism, Hinduism, Jainism, Confucianism, Daoism, Shinto, and some indigenous traditions. The project's purpose was to find religious implications (that each religion contains) relating to environmental issues; to interpret religious texts which mention the ways to protect the environment, or concrete projects that religious groups ran such as initiatives to clean the rivers or reforest, set up and manage communities living according to the natural rhythm etc. In three years, the Harvard Project on Religion and Ecology has held series of conferences entitled "Buddhism and Ecology", "Christianity and Ecology" etc. And the pinnacle of that project was the creation of the Forum on Religions and Ecology that was announced in a press conference held in 1998.

Scientists and politicians also much discussed the topic of religious ecology. Mr. Ban Ki-moon, who was the Secretary-General of the United Nation from 2007 to 2016, has stated that religious communities are important factors in the global effort to respond to the climate challenges. Religions remind us about the ethical aspects of climate change, the duty to take care of the unstable environment of the Earth, and to aid neighboring countries which are suffering natural disasters. Stevent C. Rockefeller, in Spirit and Nature: Why the Environment is a Religious Issue - An Interfaith Dialogue [1] suggested that it is necessary to mobilize leaders of top religions in the world to use the spiritual resources in countering unprecedented menaces the human beings are currently facing. In Spiritual Ecology: The Cry of the Earth [2], Llwellyn Vaughan-Lee stated that the spiritual ecology can heal the Earth's 'body' which is seriously injured by the excessive exploitation of the human beings. Alister E. McGrath, who was against the traditional viewpoint seeing science and religion as two different ways to learn about the world, argued that scientists often express a negative view on religion, regarding it as some teaching too much focusing on extramundane issues. But in reality, according to Alister E. McGrath, religions always treasure and protect the environment. Moreover, he thought that if we only look at the world within the limit of concrete sciences and regard that as the combination of atoms and molecules ruled by constant laws, then we would lose the possibility of discovering natural mysteries. Thus, we should see the world as a masterpiece of the Creator to raise human's self-awareness in protecting the nature and treasuring it as the valuable gift from the Creator [3].

The above-mentioned views of politicians and scholars show that it is necessary to understand and resolve the root cause of the environmental problems from spiritual perspective. Facing environmental problems such as resource depletion, degeneration of species, the global warming, sea level rise, overconsumption etc., we must re-examine and re-assess our attitude towards the Earth and our spiritual responsibility over this planet.

As for the religious organizations, in the present circumstance, they pay much attention to the ecological problems. The Catholic Church contends for the formation of a particular theological field called Ecotheology which is based on the Revelation of foundation, Trinitarian theology, and theological anthropology. In relation to the Trinity - Father, Son and Holy Spirit (God the Father is the Creator, God the Son is the Redeemer, and the Holy Spirit is the Sanctifier) -, every creature, the universe, the biosphere, mankind, living things, cells etc. are all in a systematical interrelation. Mankind is but a part of that system, having close correlation with other creatures, therefore mankind's interaction with others in that 
correlation is determined by him, and he must take responsibility towards God. If man dominates and exploits the nature and disturb the ecological balance, then man will receive God's chastisement. "And the Lord God took the man, and put him into the garden of Eden to dress it and to keep it." (Genesis 2:15). That spirit of the Bible assigned members of the Church the responsibility towards God for protecting the nature. Pope Ioannes Paulus II on $30^{\text {th }}$ December 1987 promulgated an encyclical entitled Sollicitudo Rei Socialis (the Social Concern) of which the main content can be summarized as follows: for centuries, man did work and transformed his own living environment. This transformation itself is in accord with the will of God, and it also means to take part in the creation of God on behalf of God. But the transformation must be made by justice and mercy, man must respect other human and other creatures, and even it is necessary to change something in them, man must consider their nature and interconnections in an organized system [4]. Thus man must not ignore that in his labor process, he is not allowed to arbitrarily use the nature and force it to obey his insatiable greed. Since doing that, man would be opposed to the nature instead of 'co-operating' with God in "his creative work", mistreat it rather than master it, and it is the very betrayal of God.

From the viewpoint of the Eco-theology mentioned above, the ecological crisis is the expression of the social crisis, thus the resolution of ecological crisis must be based on the premise that social crises were resolved. Only if the social "alienation" is abolished can the natural "alienation" be abolished. Once man keeps running after profits, excessive consumption, arms race etc., the nature is getting exhausted. Although poverty can easily lead to the moral alienation and bad conduct, but if the prosperity is built on an amoral and inhuman economy, then it also can lead the society to other awful gulfs.

Facing urgent environmental problems, those eco-theological meditations above did not stop at being theoretical, they were put into the Church's teaching. The ecology became one of the topics of great interest to the religious society. Bishop Giampaolo Crepaldi, the secretary of the Pontifical Council for Justice and Peace, has suggested 10 principles (also called "Ten Commandments for the Environment") summarized from the Compendium of the Social Doctrine of the Church, in which he asserted that, nature is a God's gift, but it is not divine itself, it cannot be absolutized and put above human dignity and intervention. Nature cannot be made into the object of the excessive exploitation; human beings must respect their positions in the ecosystem. Every development policy must be carried out in harmony with ecological policies. Most recently, in 2015, Pope Francis published the encyclical "Laudato si" with the subtitle "on care for our common home", and established $1^{\text {st }}$ September as the "world day of prayer for the care of creation".

The ecotheological basis and principles of behavior towards the environment are of increased interest from the Church and become an important part of teaching given to the believers. As long as people do not abandon morality to obey blindly economic laws and political orders, religious trust still is valuable in awakening people to protect the natural environment.

The recent contributions (that were unprecedented) of religious leaders in the 2015 United Nations Climate Change Conference held in Paris (France) are clear evidence. At that conference, the world religions issued a common statement calling the intergovernmental actions on the climate change. They associated with more than 10000 social activists, professors, clergy, and religious leaders from 73 countries and 50 faiths to adapt to the climate change.

All those activities confirm the importance and role of religions in adapting to environmental problems. 


\subsection{Practical movements of religious ecology in the world}

Based on ecological viewpoint of the religions, various new ecological movements are now expanding all over the world.

In Thailand, Sri Lanka and Myanmar, Buddhist monks often live in the forest, which helps them not only lead traditional lifestyle and do missionary work of the Earliest Buddhism, but also directly, and effectively, participate in the protection of forests. In 1988, Monk Phrakhru Manas Natheepitak (Thailand) performed an "ordination" for 50 million of trees in the presence of the King. Thanks to that, the deforestation in Thailand has decreased significantly. The movement of ordinating trees then expanded to Cambodia, Laos, Myanmar etc.

The Catholic nuns in North America had concrete activities to protect the environment, such as manually cultivating the land around convents, setting up organic farms for the community, building houses from reusable materials, building eco-friendly WCs by using green technology, using solar cells and eco-friendly vehicles, donating the churches' real property to nature reserves, etc. Those enthusiastic activities of Catholic nuns in "Green Sisters" organization have effectively contributed to the protection of ecosystem in the present ecological crisis.

For decades, Christianity in the Great Britain created and developed many websites such as God the Green, Christian ecology etc. to disseminate information about the environmental events in England and other places in the world. Information on environmental events is sent to churches to be put into their sermons and then be realized in priests' monastic life, in ordinary life of parishioners locally and worldwide. The program is run in various countries through connected networks. The Anglican Union Environment Network (AUEN), the Evangelist Environmental Network (EEN), and the European Christian Environmental Network (ECEN) inspire their believers, in the name of God, in the effort to take care of God's creations. One association for animal welfare of Christianity (which was founded in 1970) raised public awareness of the duty to take care of animals (especially endangered species), prevent the animal cruelty in breeding farms and laboratories. The Plant With Purpose, a Christian nonprofit organization, was founded to prevent the deforestation and poverty around the world by changing life of the poor in rural areas. A campaign of the Christianity in England, sponsored by Christian Aid, was run to help political parties realize their statements and policies on climate change before general elections. Thoughts on sources of all ecological crises from the Christian theological viewpoint are put into textbooks and lectures presented to students at many universities around the world.

\subsection{Some remarks}

The practical movements for ecosystem mentioned above which rose and be inspired by the theology of different religions have more or less changed social attitude and behavior towards environmental issues. Thus, we should not only consider religions in terms of epistemology, religious approach to truth, or institutions and doctrinal texts, but also regard them from statistics: nearly $100 \%$ of countries in the world has connection with some religion, the believers account for over $90 \%$ of global population (with nearly 2 billion Muslims, nearly 2 billion Christians, above 1 billion Buddhists, above 1 billion Confucianists, above 1 billion Hinduists, and the rest admit and worship the indigenous folk beliefs). Confucianism and Daoism are rising up, Buddhism, Islam, Christianity are practiced widely in many Western and Eastern countries. Religions are present in all spheres of politics, economics and of course in cultural space, morality, and lifestyle of the mass. 
That is the reason why in the United Nations Environmental Program, religious organizations are regarded as the strongest forces on the Planet that need to be connected and mobilized in resolving environmental issues.

Numerous religions have given moral orders for their followers to take care of the Earth, thus the believers usually pay more attention to the environment than other people. Some religious organizations have been ahead of social-political organizations in founding movements for environmental protection. Still, they also care about countries and marginalized groups suffering damage when environmental disasters occur all over the world.

We all are living a challenging period. The environmental chaos and climate changes that we are facing lead us to a desperate feeling. Our economic and political institutions seem to end in failure. It is said, from some negative viewpoints, that this will be the last collapse of mankind when the ecosystem collapses. In desperation and with an unsecure feeling about bleak future, scientists and politicians come back to the traditional philosophies and religious ecology, and it is not an intellectual pastime. Those philosophical traditions are reconsidered and reproduced to find ways to resolve environmental issues.

Numerous countries are successful in taking advantage of religious organizations and movements' capital and human resources to improve the society and environment, and they achieve practical results.

\subsection{Ecological themes in some religions in Vietnam}

In Vietnamese three-teaching (Confucianism, Buddhism, Daoism) tradition, there have been from earliest times ideas of the harmony between man and the nature, of the cultivation of man aiming to the harmonious relation between man and the nature.

Buddhist teaching states that, the Universe is the Great Trichiliocosm, man is the Small Chiliocosm (the miniature universe), thus man has characteristics of the universe that control man's development. Both Great Trichiliocosm and Small Chiliocosm change regularly along the circulation of birth - stay - change - death. Although Buddhist classics concentrate on teaching ways to escape the valley of tears (the life) to the people, they still contain many theories of the interrelation between man and the nature that is called "hetupratyaya" (chain of cause and effect) in Buddhist words. The important meaning of the principle of 'hetupratyaya' is that every action has its inevitable effects, and those effect will sooner or later react on the very subject of the first action. That principle of cause and effect does not only apply to the human world but also to the physical world. Thus, in Buddhist viewpoint, "you reap what you sow", "sowing wind, reaping a storm". In the relation with the nature which is called 'the others' in Buddhist words (that means all things in nature are regarded as others existing together with man), man must not ignore the principle of cause and effect: nothing can exist separately, everything must depend on others and exist harmoniously with others. This thing is then that thing will be; this thing is not then that thing will not be; this thing forms then that thing will form, this thing dies then that thing will die...

Daoism promotes the theory of "wu wei" (no action/inaction or no creation), which is also called "Heaven's way" (that is mean acting naturally, doing nothing against what the Heaven has determined). "No action" of the Daoism does not mean doing nothing, but not doing things according to private opinion and desires and against the nature. Laozi advised man to act according to the nature and not to act forcefully or under the influence of greed. The theory of "no action" has had a widespread influence over Vietnamese spirit and mind. In the relation with the nature, that theory means the respect for the natural rules, the view according to which man should not control or intervene too much in the nature, not to ruin the balance of the universe, the world, and all things. 
Confucianism (especially the first phase of it, called 'pre-Qin Confucianism') thinks that between the Heaven and man there is the interrelation ("interrelation between Heaven and man", "mutual interaction between Heaven and man", "the unity of Heaven and man" in Confucian words). Heaven and man unite in a One. That means natural phenomena have the influence over human morality, and vice versa, human morality can impact on the nature: "There are the favorable verifications: namely, of gravity, which is emblemed by seasonable rain; of orderliness, emblemed by seasonable sunshine; of wisdom, emblemed by seasonable heat; of deliberation, emblemed by seasonable cold; and of sageness, emblemed by seasonable wind, There are (also) the unfavorable verifications - namely, of recklessness, emblemed by constant rain; of assumption, emblemed by constant sunshine; of indolence, emblemed by constant heat; of hastiness, emblemed by constant cold; and of stupidity, emblemed by constant wind" [5]. Confucius stated that cultivated man must respect the nature, if man live in accordance with the nature then the nature will respond favorably with seasonable and fine weather, abundant crops, and prosperity for him. Thus, ancient Kings always emphasize the self-improvement to win over the Heaven's heart, once the climate and geographical position are favorable, and the people support the king, will the king's throne be stable and durable, the people live in a happy life and not revolt.

In brief, all Confucianism, Buddhism and Daoism have ideas of the harmony between man and the nature. Vietnamese people have the intention of pursuing the harmony with the nature, that is why the word "Heaven", or "Sky", is commonly present in Vietnamese writings and thought. In the opinion of Vietnamese people, the word "sky" or "heaven" means the very nature that is existing in the relation with man, not the world of Gods as in mind of Western people. The nature is identified with "heaven", and the term "heaven" refers to three meanings as follows: (i) the natural world with cloud, rain, thunder, lightning etc.; (ii) a good force protecting good people, punishing bad people, and cultivating all things; (iii) one of three factors (also called "three body" including "Heaven", "Man", Earth") in which man is the mediator connecting the Heaven and the Earth. Man, the Heaven and the Earth are three basic factors forming the cosmology of Vietnamese people.

The thought on living in harmony with nature contained in the three teachings has a deep influence over the lifestyle of Vietnamese people. For instance, the polyculture in which different trees are planted in the same land, or the burn shifting cultivation etc. of the ancient Vietnamese can be seen as exploiting and protecting the forest, reforesting at the same time. Some ethnic groups, both ancient and modern, never catch fish in calm waters, because these are places where mother fishes enter to spawn, they think that if they catch those mother fishes, there will be no fish in rivers and streams afterwards...

Based on that thought of Confucianism, Buddhism and Daoism on the relation between man and nature, Vietnamese people have acquired general knowledge of nature and understood how to grasp the essence of the nature to live a harmonious life with the nature. Vietnamese people have put their knowledge into practice to self-control and become free in front of the nature. They understood which aspect the house should face to have health benefits, how to harmonize the yin and yang in their own bodies to improve the health and unify themselves with nature into an entity. They knew which trees and animals are suited to climate and natural conditions that they should plant. On the other hand, when Vietnamese people adapted to the nature and could transform and improve the nature to a certain extent, they also became stronger, more flexible, and more active that they could counter and minimize effects of natural disasters better than people who lived in a milder climate.

However, during the last decades, Vietnamese population increased rapidly, the need for sustenance was growing to the extent that the environment was excessively exploited and destroyed. People deforested to get wood, killed wild animals for food, overfished, extracted groundwater for everyday use, used lots of pesticides, exploited mineral deposits 
to export etc. By accident, the Vietnamese people nowadays, to making a living, are turning their back on their own natural environment.

The visible and negative effects are that Vietnam is now facing serious environmental problems such as sea level rise, the increase of carbon emissions, water and air pollution, deforestation in watersheds, exhaustion of natural resources, etc. According to a Report of the World Bank in 2007, Vietnam is one of five countries worst affected by the climate change. In 2100 the temperature is forecast to rise by about $3^{\circ} \mathrm{C}$, and the sea level in Vietnam by about $1 \mathrm{~m}$. At that time, about $40.000 \mathrm{~km} 2$ of coastal plains of Vietnam will be submerged, $90 \%$ of Cuu Long river delta will disappear [6]. Each year about 200.000ha of forests are lost (50.000 ha of which are reclaimed to cultivate). With the current rate of deforestation, as of 2040 , there are 20 to 70 of species will be extinct each day. The forests are lost, $\mathrm{CO} 2$ is not absorbed, greenhouse effects will intensify, the global warming will cause the thaw and the rise of sea level. In addition, the hard industry and the uncontrolled exploitation of natural resources are discharging hazardous substances to environment and making land, water, air etc. polluted.

The ecological crisis will change people's life, and ruin economic-social development plans and targets of Vietnam. It will at first affect the agriculture and the population involved in agricultural production (who constitute $86 \%$ of the country's population), lower the budget revenue and reduce the State's ability to respond to the social welfare. The ecological crisis will also lead to social conflicts: people who lost their jobs in the agricultural production but cannot find other jobs will fall into poverty and feel marginalized, disappointed, and dissatisfied, therefore easily gather to revolt. The environmental crisis will also cause the uncontrolled immigration, the ethnic and cultural conflicts. Advocacy groups will increase. On the other hand, the environmental pollution will affect to the health of all population, wealthy or poor. The insecurity and anxiety about their own health can lead them to the anger towards the State and government. That occurred in reality when some economic projects which may cause the environmental pollution, such as Formosa Steel plant project (Ha Tinh province), Bauxite mining project (in the Central Highlands), Nuclear power plant project (Ninh Thuan province) etc., had been approved.

The standards and principles which formed the relation between man and ecosystem that traditional religions (Confucianism, Buddhism, Daoism) established - such as limiting the growth rate, coming back to the nature, not acting, living a self-sufficient and closed life in harmony with the nature etc. - though were more or less successfully applied in the past, are no longer compatible with the present circumstances. It is not that the ecological theories of those religions now lack the ability to be put into practice, but they are now facing the present paradoxes of the society: the population increases, sciences and technology develop, and as the result, the possibility of exploiting and transforming the nature is getting higher, the nature is getting more injured and damaged. But if human need is eliminated to stop exploiting natural resources and destroying environment, then the law of supply and demand will be broken, the production will fall, the economy will be sunk into recession, many people will become unemployed etc.

\subsection{Vietnamese religions' practical movements relating to environment}

In Vietnam nowadays, religious people account for about $27 \%$ of the population, and almost all the rest admit folk culture and indigenous beliefs. The story of environment in the present Vietnam can be summarized in one statement that the people just worry about how to earn a living, and the managements/authorities worry about how to prevent the people from damaging the nature. Scientists, managements, and politicians are trying in vain to adapt to the climate change, natural resource exhaustion and environmental 
pollution. However, every solution is but the so-called 'cleaning up' the effects. The root of environmental protection must be found in the change of people's lifestyle and awareness of values and needs. From this aspect, it can be said that the participation of religions is possible and useful.

While the scientists and public authorities have not yet improved the legal system to control the people's activities and protect the environment, religious organizations in Vietnam run series of campaign on environmental protection. Many programs and activities of them has achieved positive results and tended to expand in both aspects of scale and mode of operation.

As regards Buddhism, monks and nuns encourage the believers to realize a philosophy of life of "thiểu duc, tri túc" (content with few desires), to reduce the pressure on the environment and natural resources. They also advise believers to practice meditation to limit three emotions - desire/greed, hatred and delusion/ignorance - in consuming and enjoying things. In addition, believers are taught to take care of trees and animals, cut down the use of digital tools to be closer to the nature and protect the environment. By mass media such as CDs, books, documents, Buddhist Church appealed the people to heighten the awareness and responsibility for protecting the environment. They launched the movement for tree planting and reforest called "planting blessing trees", "reforesting lands around pagodas" etc. They also mobilized people to use fresh water and regularly cleaning the surrounding environment. The Most Venerable Thich Pho Tue, the supreme patriarch of the Buddhist Sangha of Vietnam, has transmitted a message in which he appealed to all believers for the environmental protection on Vesak day in 2011. He said: "The world in general and our country in particular are facing many serious difficulties caused by the climate change and environmental crisis. Natural resources are getting exhausted, the global warming is getting worse, many disasters such as droughts, floods, pandemics, tsunamis, earthquakes, sea level rise etc. are threatening human life. Therefore, more than ever, I urge each of our Monk, Nun, Buddhist follower to be aware of the essence of Buddhist teaching on the anitya (impermanence), the respect for life and the organic relation between man and nature, to cooperate with social community in protecting environment and the Earth's survival. That will be practical activity to offer up to the Buddha, our fond father" [7].

As for Catholicism, through some surveys carried out in some Vietnamese villages where Catholic and non-Catholic communities live together, Vietnamese scholars reached the judgment that there is an obvious difference between their opinions on the living environment. In and around Catholic families or families that have close connection with Catholic people, more trees are planted, and the place is also cleaner and airier. Their houses and even hygienic areas are well planned. The churchyard is more ordered than the graveyard of non-Catholic people. After religious ceremonies, churches and chapels are cleaner, there is no bottle, cigarette butt, food waste messily thrown like in cultural activities of non-religious people [8].

As for the Protestantism, in front of the current environmental and ecological challenges, Vietnamese Protestants also are well aware of the close connection between man and nature and the responsibility for protecting and living harmoniously with the nature. That awareness is expressed in the Protestants' practical activities and movements, and their active appeal for the importance of the environmental protection. In the Central Highlands where a large number or Protestants are living, and where the watersheds are terribly destructed as well, there are 374 of 400 believers questioned who have listened to the talks about environment, according to a survey result. Among the information of great interest, such as job, housing, democracy, law, economy, environment, people also pay a special attention to the environment (at a rate of $83 \%$ ). The people gain the information about environment mainly through dignitaries' teachings. They gradually are aware of the importance of environmental protection and stop deforesting and using the slash and burn 
agriculture. Protestant groups when registering for religious activity are always required to follow sanitation rules and protect the environment. Some Protestant Churches, when carrying out the charitable activities in low living standard areas, pay the first attention to the provision of sanitary facilities and fresh water for believers' families [9]. It is said that, though Vietnamese Protestantism does not tend to establish an eco-theology or environmental movement, Protestant believers are imbued with the importance of environmental protection which can be seen obviously in their friendly attitude towards the environment.

Besides, houses of worship of all religions are built in harmony with the ecosystem with trees and water (ponds or lakes) all around. In addition, where there is church or pagoda, or place associated with a sacred legend, there is the full environmental protection. Religions and beliefs there play the role as "magical guardian" that poachers dare not harm. Sometimes in Vietnam, the religious holiness can help limit the deforestation and increase the people's awareness of environmental protection better than legal sanctions, political orders, or scientific measures. Some primeval forests, such as Va forest (Son Tay), Y Ty forest (Lao Cai province), Cam forest (Ha Giang province), Mieu Cam forest (Quang Nam province), $\mathrm{Cu}$ Hlam forest (Daklak province), are called 'sacred forests' thus be protected not by laws made by the government but magical customary laws. There is no sign "deforestation is prohibited" in those forests, but no one dare cut down the trees. People living there believe that their ancestors and Gods of the community inhabit in the forest, especially in old trees, and hence they think that chopping trees will lose the residence of Gods. They even hardly gather wood there, let alone the deforestation.

Table 1. The percentage of believers in provinces and cities participating in the environmental protection movement. Source: Ministry of Natural Resources and Environment, National Environment Report 2010.

\begin{tabular}{|c|c|c|c|c|c|}
\hline No & Province, city & $\begin{array}{c}\text { The percentage of } \\
\text { believers in the total } \\
\text { population (\%) }\end{array}$ & No & $\begin{array}{c}\text { Province, } \\
\text { city }\end{array}$ & $\begin{array}{c}\text { The percentage of } \\
\text { believers in the total } \\
\text { population (\%) }\end{array}$ \\
\hline 1 & Binh Phuoc & 22 & 24 & Kien Giang & 29.24 \\
\hline 2 & Ba Ria Vung Tau & 60 & 25 & Kon Tum & 41.72 \\
\hline 3 & Bac Lieu & 28 & 26 & Lang Son & 1 \\
\hline 4 & Bac Giang & 1.65 & 27 & Lao Cai & 1.77 \\
\hline 5 & Bac Kan & 5 & 28 & Lam Đong & 60 \\
\hline 6 & Bac Ninh & 20 & 29 & Long An & 25 \\
\hline 7 & Ben Tre & 15.16 & 30 & Nghe An & 8.7 \\
\hline 8 & Binh Đinh & 10.63 & 31 & Ninh Binh & 23.33 \\
\hline 9 & Binh Thuan & 39.6 & 32 & Ninh Thuan & 37 \\
\hline 10 & Ca Mau & 27.6 & 33 & Phu Tho & 11.57 \\
\hline 11 & Can Tho & 33 & 34 & Phu Yên & 30 \\
\hline 12 & Đak Lak & 24.5 & 35 & Quang Ninh & 15 \\
\hline 13 & Dien Bien & 1.6 & 36 & Quang Tri & 0.12 \\
\hline 14 & Đong Thap & 23 & 37 & Thanh Hoa & 5 \\
\hline 15 & Thanh Hoa & 5 & 38 & Thai Binh & 21.4 \\
\hline 16 & Ha Giang & 4.44 & 39 & Thai Nguyên & 7 \\
\hline 17 & Ha Nam & 23.7 & 40 & Tra Vinh & 51 \\
\hline 18 & Ha Noi & 2.69 & 41 & Tien Giang & 9.33 \\
\hline 19 & Ha Tinh & 12 & 42 & Tuyen & 5.67 \\
\hline 20 & Hai Duong & 11 & 43 & Soc Trang & 48.54 \\
\hline 21 & Hai Phong & 25 & 44 & Son La & 0.74 \\
\hline 22 & Hau Giang & 23.04 & 45 & Vinh Long & 20 \\
\hline 23 & Khanh Hoa & 30 & 46 & Yen Bai & 6.9 \\
\hline & & & & & \\
\hline
\end{tabular}




\section{Conclusion}

Ecology is a part of the teachings and worship rituals of all religions in Vietnam. Based on religious teachings, religions in Vietnam actively get involved in the work of environmental protection.

The number of believers in Vietnam is increasing, and the influence of religions also extends to every social field. Thus, it is effective to mobilize religious resources for the environmental protection. Religious organizations in Vietnam can also learn from models and experiences of international religious organizations in protecting the environment.

Almost no religious ecological movement in Vietnam is of such large scale as international movements are. The reasons vary: (i) there is still limitation in the awareness of the Vietnamese on the importance of ecosystem; (ii) the population explosion put a considerable pressure on the ecosystem, but the Vietnamese people are not prepared to adapt; (iii) the difference in ideology between the State and religions cause a political preconception about religious organizations, hence the State has not yet paid enough attention to them and established favorable policies for them to participate in the environmental protection; (iv) religious organizations in Vietnam have not yet made every endeavor to the social activities, and they still lack experiences of organizing movements for environment, etc.

In coming years, Vietnam must change in the awareness of the environment, that the environmental problems cannot only be regarded from natural and economic aspects, but also from political and national security ones. The environmental crisis is a serious challenge to the national security, especially the political security. The State and all civil organizations and communities must promptly and actively participate in the environmental protections. And there must be favorable policies and rules for religious organizations to take part in that important work.

\section{References}

1. S.C. Rockefeller, Spirit and Nature: Why the Environment is a Religious Issue - An Interfaith Dialogue (Beacon Press, Boston, 1992)

2. Llewellyn Vaughan-Lee, Spiritual Ecology: The Cry of the Earth (Golden Sufi Center, California, 2003)

3. The Reenchantment of Nature: The Denial of Religion and the Ecological Crisis (Doubleday / Galilee, New York, 2003)

4. Pope Ioannes Paulus II, Sollicitudo Rei Socialis (1987)

5. Eastern thought suggests references (Literature Publishing House, Hanoi, 1995) (https://ctext.org/shang-shu/great-plan).

6. National Target Program to respond to climate change (Ministry of Natural Resources and Environment, Hanoi, 2008)

7. Thich Pho Tue, Vesak Day Message (2011)

8. Nguyen Quang Hung, Roles of religions in protecting environment in Vietnam, http://btgcp.gov.vn

9. Ngo Quoc Dong, Proceedings of conference: Religions and sustainable development in Central Highlands: viewpoints and solutions (Hanoi, 2014)

10. J. Clark, S. Stroope, Social Science Research 70, 242-253 (2018) 